\title{
COMPARISON OF CARDIOVASCULAR, RESPIRATORY, AND \\ METABOLIC EFFECTS OF HALOTHANE-ETHER AZEOTROPIC MIXTURE WITH THOSE OF METHOXYFLURANE ANAESTHESIA \\ IN MAN*
}

R Dery, M D, FR P P (C), J Pelletier, M D, AND

A JACQUES, C D, MCD, F R C P (C)

SiNCE ITS INTRODUCTION by Hudon, the halothane-ether azeotropic mixture has earned a place of its own in the armamentarnum of anaesthesia Numerous studies have given detalled consideration to the clinical aspects of its administration and stated factual information about its convenience, safety, and virtual lack of unpleasant side-effects Adverse comments and controversial attitudes, sometimes based on casual trial, nonetheless bespeak the influence exerted by this azeotrope among other established agents Particular attention has been given to its cardiovascular actions by Wyant, ${ }^{1}$ Dobkın, ${ }^{2}$ Déchêne ${ }^{3}$ and their collaborators The interpretation of their measurements, however, remains difficult because their studies are purely pharmacological, conducted outside the operating room and in known artificial conditions The validity of their methods rests on solid foundations, and this study does not intend to refute their conclusions However, their lesults can hardly be said to be those which one will encounter in dally practice Everybody will agree that surgery is a far greater physiological stress to the patient than anaesthesia, and this fact should not be ignored when one is dealing with the respiratory and cardiovascular activity of patsents who, usually, are anaesthetized for and during surgery

The purpose of this report is to evaluate the vanous physiological responses associated with the administration of halothane-ether azeotrope in patients who at the same time were submitted to minor surgical procedures The virtue of this approach, as stressed by Price, ${ }^{4}$ is that it describes changes which occur under conditions likely to met in everyday practice In a preceding paper, we have described the pharmacological effects of methoxyflurane during surgical anaesthesia in man ${ }^{5} \mathrm{As}$ both studies were conducted in exactly the same way, we shall take the opportunity to draw a comparison between these two drugs

\section{Materials and Methods}

The experiments were carned out on 20 patients, 7 males and 13 females Their mean age was 453 years, the extremes being 21 and 76 years History, physical examination, $\mathrm{X}$-rays of the chest, and electrocardiogram were obtamed in all patients, along with routine laboratory tests, and revealed no evidence of

"From the Depurtment of Anatsthesıa and Feanimation, Hôtel-Dieu de Québec, Québec, PQ Prosented at the Annual Meeting Canadian Anacsthctists Soc 1ety, May 10-14, 1964 
organic systemıc disease Haemodynamıc and respiratory studies were conducted in 9 of these patients, and additional data pertinent to metabolic and endocrine functions were obtained from 11 other patients anaesthetized under sumilar conditions

The method used has been described in a previous publication ${ }^{5}$ Briefly, it involved the serial determination, before, durng, and after anaesthesia, of

(a) Pulmonary ventilation This was obtained fiom a Wright Ventilometer attached to the mask and located in front of the rebreathing circle

(b) $\mathrm{CO}_{2}$ concentrations in expired gas This was monitored continuously on the Godart Capnograph and recorded on the Omniascriptor $\mathrm{CO}_{2}$ output per minute was obtained from planimetric measurement of the area under the curve of $\mathrm{CO}_{2}$ concentration

(c) Artenal and mixed venous blood gas tensions Arterial blood was collected through a 21-gauge Lindeman needle inserted into the brachial artery, mixed venous blood was obtained from a $\mathrm{PE}$ catheter 20 mches long fed through a 15-gauge needle driven into an elbow vem Such catheters are very pliable and are readily manipulated centrally, the direction of blood flow guiding them In a few cases, radio-opaque material was injected down the venous catheter and a subsequent roentgenogram showed its distal end to be well placed in the inght atrium or at the lower end of the superior vena cava Additional evidence of this fact was gained by the measurement of venous pressure through the catheter this pressure was invariably below $5 \mathrm{~cm} \mathrm{H}_{2} \mathrm{O}$, a figure quite suggestive of its central location Samples of blood were removed at a steady rate over a period of 30 seconds each, in order to obtain a sample representative of the avelage cardiovascular dynamics durmg this particular minute while other measurements were being made Samples were at once analysed for $\mathrm{pH}, \mathrm{PCO}_{2}$ and $\mathrm{PO}_{2}$ on an Epsco Medical Blood Parameters Analyser, Model 101, of the null detector type, working at a standard temperature of $37^{\circ} \mathrm{C}$

Arterial systolic and diastolic pressures were stethacoustically monitored through a mercury Baumanometer Pulse rate and electrocardıogram were supe1vised with a Corbin Farnsworth Scopette

The cardiac output was determined by the carbon dioxide direct Fick technique, as descibed in our previous study This method, in our hands, yıelds 1 eproducible results Values of cardiac output at rest, before and after anaesthesia, agree with accepted standards for patients of the age and sex of our patients Total peripheral resistance was calculated by dividing the mean arterial pressure by the cardiac output, as indicated by Aperia in his classic formuld ${ }^{6}$

$$
\frac{\text { mean arterial blood pressurc }}{\text { cardiac output in } \mathrm{c} \mathrm{c} / \mathrm{sec}} \times 1332=\text { dynes } / \mathrm{sec} / \mathrm{cm}
$$

Particular attention was pard to the obtaming of a steady state before any blood sampling was performed The presence of this state was appreciated by the similarity of several consecutive determinations of pulmonaly ventilation, and by the stability of the $\mathrm{CO}_{2}$ curve pattern as recorded from expired an

some degree of sedation was found to be desilable before our patients were 
submitted to this set-up Hence, they received, one hour before the operation, a moderate dose of meperidine along with atıopine $04 \mathrm{mg}$ Anaesthesia was induced by mhalation through the mask of a mixture of 2 litres of oxygen, 2 litres of nitrous oxıde, and halothane-ether azeotrope in concentrations up to 5 per cent, depending on the patient's response No patient objected to this induction, which was smooth, never stormy, and frce of any adverse reaction Sleep was produced very quickly, within 2 minutes, and operative conditions were obtained in 4 to 6 minutes Surgical anaesthesia was mantaned with halothane-ether vaporized through a Vermitrol Vaporizer using a semi-closed system with 4 lities/min total gas flow and not less than 50 per cent oxygen mixed with nitrous oxide Stable maintenance, free of pain, reflexes, or overdosage, was obtained with concentrations of azeotrope fluctuating between 12 per cent and 25 per cent We should like to emphasize at this point that we have attempted to eliminate many factors which might interfere with the study of pharmacological actions of halothane-ether azeotropic mixture, such as the administration of a showacting barbiturate at induction, endotracheal intubation, positive pressure in the airway either by assisted or controlled respiration, curares, solutes or blood transfusion Anaesthesia was kept at a moderate level, generally between the second and thrrd planes of surgical stage III, as assessed by the absence of muscular movement in response to surgical stimulation, and by other standard Guedel criteria Respiration was left unassisted throughout

\section{RESUlts}

\section{Respiratory Effects}

Table I shows the minute volume of ventilation, the rate of breathing, and $\mathrm{CO}_{2}$ tensions in arterial blood before, during, and after halothane-ether anaesthesia Respiration before induction of anaesthesia was sometimes slightly depressed, likely owing to the premedicatıon just received Maintenance during surgery, at the level of narcosis used, was attended by no respiratory depression The mean pulmonary ventilation before anaesthesia was $6465 \mathrm{c} \mathrm{c}$, during surgery, $6877 \mathrm{c} \mathrm{c}(P>005)$, after surgery, it rose to $8400 \mathrm{c}$ c This significant increase after surgery illustrates two properties of the azeotrope weak analgesia at emergence and virtual absence of respiratory depression in the recovery $100 \mathrm{~m}$ In any case, $\mathrm{PCO}_{2}$ remained well between 36 to $45 \mathrm{~mm} \mathrm{Hg}$, a range considered as normal by most laboiatories With methoxyflurane, as we pointed out in our previous study, the pulmonary ventilation remained adequate for noimal gas exchange in moderate levels of anaesthesia Most probably, the depressive effect of these two drugs was counteracted by stimuln from the operative site However, theie is a clear-cut differ ence between respiratory patterns with these two agents With halothane-ether, there is a remarkable tiend towards tachypnoea, a phenomenon well known with halothane alone, in our 9 patients, the rate rose from 19 to 27 per minute, a mean increase of 37 per cent $(P<002)$ Hence it is possible that $\mathrm{PCO}_{2}$ rises even if total pulmonary ventilation seem's at first to be acceptable, alveolar hypoventilation beirg chiefly the result of an increase in 
TABLE I

Respiratory Data Preceding and Accompanłing the Administration of Halothane-Ether to 9 Patients Breathing Spontaneously

\begin{tabular}{|c|c|c|c|c|c|c|}
\hline Patient & $\begin{array}{l}\text { Time } \\
(\mathrm{min})\end{array}$ & $\begin{array}{c}\text { Pulmonary } \\
\text { ventilation } \\
(\mathrm{L} / \mathrm{min}) \\
\end{array}$ & Frequency & $\underset{(\mathrm{mm}}{P} \stackrel{P}{\mathrm{H} g})$ & $\begin{array}{l}\mathrm{CO}_{2} \text { output } \\
(\mathrm{c} \mathrm{c} / \mathrm{min})\end{array}$ & $\begin{array}{c}\text { Halothane- } \\
\text { ether } \\
\text { concentration } \\
(\%)\end{array}$ \\
\hline 1 & $\begin{array}{r}-15 \\
15 \\
30 \\
60 \\
90\end{array}$ & $\begin{array}{l}4640 \\
5130 \\
6050 \\
8150 \\
6750\end{array}$ & $\begin{array}{ll}13 & 7 \\
13 & 1 \\
29 & 7 \\
45 & 8 \\
19 & 8\end{array}$ & $\begin{array}{ll}40 & 1 \\
46 & 4 \\
48 & 4 \\
44 & 1 \\
39 & 8\end{array}$ & $\begin{array}{ll}185 & 6 \\
165 & 7 \\
183 & 9 \\
244 & 5 \\
259 & 2\end{array}$ & $\begin{array}{ll}5 & \\
2 & 5 \\
2 & 5\end{array}$ \\
\hline 2 & $\begin{array}{r}-15 \\
20 \\
45 \\
60 \\
105\end{array}$ & $\begin{array}{l}3700 \\
4570 \\
5650 \\
6250 \\
4175\end{array}$ & $\begin{array}{ll}24 & \\
21 & 4 \\
27 & 7 \\
30 & 6 \\
36 & 1\end{array}$ & $\begin{array}{ll}47 & 6 \\
44 & 2 \\
40 & 1 \\
44 & 1 \\
46 & 3\end{array}$ & $\begin{array}{rl}95 & 9 \\
155 & 3 \\
167 & 9 \\
137 & 5 \\
78 & 5\end{array}$ & $\begin{array}{ll}4 & \\
2 & \\
2 & 5\end{array}$ \\
\hline 3 & $\begin{array}{r}-15 \\
30 \\
60 \\
75 \\
110\end{array}$ & $\begin{array}{r}9600 \\
7125 \\
10180 \\
6350 \\
7600\end{array}$ & $\begin{array}{l}20 \\
32 \\
26 \\
20 \\
18\end{array}$ & $\begin{array}{ll}30 & 5 \\
55 & 7 \\
39 & 6 \\
43 & 0 \\
36 & 9\end{array}$ & $\begin{array}{l}288 \\
213 \\
315 \\
219 \\
266\end{array}$ & $\begin{array}{l}3 \\
2 \\
2\end{array} 5$ \\
\hline 4 & $\begin{array}{r}-15 \\
20 \\
45 \\
90 \\
120 \\
150\end{array}$ & $\begin{array}{l}3050 \\
5100 \\
4000 \\
6300 \\
6000 \\
6000\end{array}$ & $\begin{array}{l}22 \\
30 \\
29 \\
30 \\
28 \\
20\end{array}$ & $\begin{array}{ll}37 & 5 \\
35 & 3 \\
35 & 5 \\
36 & 8 \\
37 & 5 \\
38 & 1\end{array}$ & $\begin{array}{rl}93 & 5 \\
163 & 8 \\
116 & 0 \\
151 & 2 \\
126 & \\
180 & \end{array}$ & $\begin{array}{ll}4 & \\
2 & 5 \\
2 & \\
0 & 5\end{array}$ \\
\hline 5 & $\begin{array}{r}-15 \\
25 \\
60\end{array}$ & $\begin{array}{r}13450 \\
8400 \\
11100\end{array}$ & $\begin{array}{ll}20 & \\
20 & 5 \\
17 & 5\end{array}$ & $\begin{array}{ll}38 & 2 \\
45 & 4 \\
37 & 7\end{array}$ & $\begin{array}{l}484 \\
4964 \\
399\end{array}$ & 25 \\
\hline 6 & $\begin{array}{r}-15 \\
40 \\
60 \\
75 \\
120\end{array}$ & $\begin{array}{l}6353 \\
6220 \\
6530 \\
6700 \\
8130\end{array}$ & $\begin{array}{l}24 \\
14 \\
16 \\
17 \\
26\end{array}$ & $\begin{array}{ll}40 & 1 \\
42 & 8 \\
45 & 2 \\
44 & 6 \\
38 & 9\end{array}$ & $\begin{array}{ll}206 & 7 \\
279 & 9 \\
271 & 6 \\
274 & 7 \\
243 & 9\end{array}$ & $\begin{array}{l}5 \\
2 \\
1 \\
1\end{array}$ \\
\hline 7 & $\begin{array}{r}-15 \\
15 \\
30 \\
90 \\
105 \\
120\end{array}$ & $\begin{array}{l}4700 \\
7240 \\
8830 \\
9200 \\
8600 \\
9600\end{array}$ & $\begin{array}{l}13 \\
20 \\
21 \\
26 \\
26 \\
21\end{array}$ & $\begin{array}{ll}39 & 3 \\
33 & 8 \\
36 & 1 \\
37 & 8 \\
36 & 2 \\
29 & 6\end{array}$ & $\begin{array}{ll}194 & 6 \\
249 & 7 \\
284 & 3 \\
338 & 5 \\
286 & 3 \\
330 & \end{array}$ & $\begin{array}{ll}5 & \\
2 & 5 \\
2 & 5 \\
2 & 2\end{array}$ \\
\hline 8 & $\begin{array}{r}-15 \\
30 \\
45 \\
90 \\
120\end{array}$ & $\begin{array}{r}6050 \\
5000 \\
9300 \\
9250 \\
10750\end{array}$ & $\begin{array}{l}20 \\
25 \\
40 \\
32 \\
30\end{array}$ & $\begin{array}{ll}40 & 7 \\
44 & 5 \\
41 & 5 \\
45 & 5 \\
39 & 6\end{array}$ & $\begin{array}{ll}229 & 9 \\
170 & \\
297 & 6 \\
259 & \\
357 & 9\end{array}$ & $\begin{array}{ll}2 & 5 \\
2 & 5 \\
1 & 2\end{array}$ \\
\hline 9 & $\begin{array}{r}-15 \\
30 \\
60 \\
90 \\
120 \\
180\end{array}$ & $\begin{array}{l}6650 \\
6100 \\
7850 \\
5700 \\
6800 \\
8400\end{array}$ & $\begin{array}{l}21 \\
37 \\
37 \\
32 \\
33 \\
22\end{array}$ & $\begin{array}{ll}35 & 8 \\
40 & 4 \\
42 & 1 \\
38 & 5 \\
35 & 3 \\
40 & 2\end{array}$ & $\begin{array}{ll}242 & 7 \\
183 & \\
329 & 7 \\
193 & 8 \\
251 & \\
252 & \end{array}$ & $\begin{array}{ll}2 & \\
1 & 2 \\
1 & 2 \\
1 & \end{array}$ \\
\hline
\end{tabular}

dead volume ventilation With methoxyflurane, most observers agree that the respiratory rate progressively decreases during the course of anaesthesia, shallow bradypnoea always indicating very deep narcosis

$\mathrm{CO}_{2}$, output may be used indirectly to appreciate the basal metabolic rate during anaesthesia There is a well-known relationship between cardiac output 
and body metabolism ' $\triangle$ Therefore, it is reasonable to suspect that the administration of a drug which lowers $\mathrm{O}_{2}$ consumption and $\mathrm{CO}_{2}$ production could also be attended by a low cardiac output, and vice versa Methoxyflurane usually induced a significant depression of $\mathrm{CO}_{2}$ production and elimination, from a mean of $240 \mathrm{c} \mathrm{c}$ before anaesthesia to a mean of $199 \mathrm{c} \mathrm{c}$ during anaesthesia The azeotrope, however, seems to cause a very slight increase in $\mathrm{CQ}_{2}$ output Before anaesthesia, the mean $\mathrm{CO}_{2}$ output was $224 \mathrm{c} \mathrm{c}$, during maintenance, $232 \mathrm{c} \mathrm{c}$, a difference too small to be of statistical value $(P>005)$, but nevertheless indicative of a positive tendency Diethyl ether has been shown to produce hypermetabolism during anaesthesia, possibly ciwing to a release of epınephrine and central sympathetic stimulation ${ }^{9} 10$

\section{Metabolic Effects}

Figure 1 presents a summary of the relationshp between $\mathrm{PCO}_{2}, \mathrm{pH}$, and $\mathrm{CO}_{2}$ content in the arterial blood of our 9 patients anaesthetized with the azeotrope

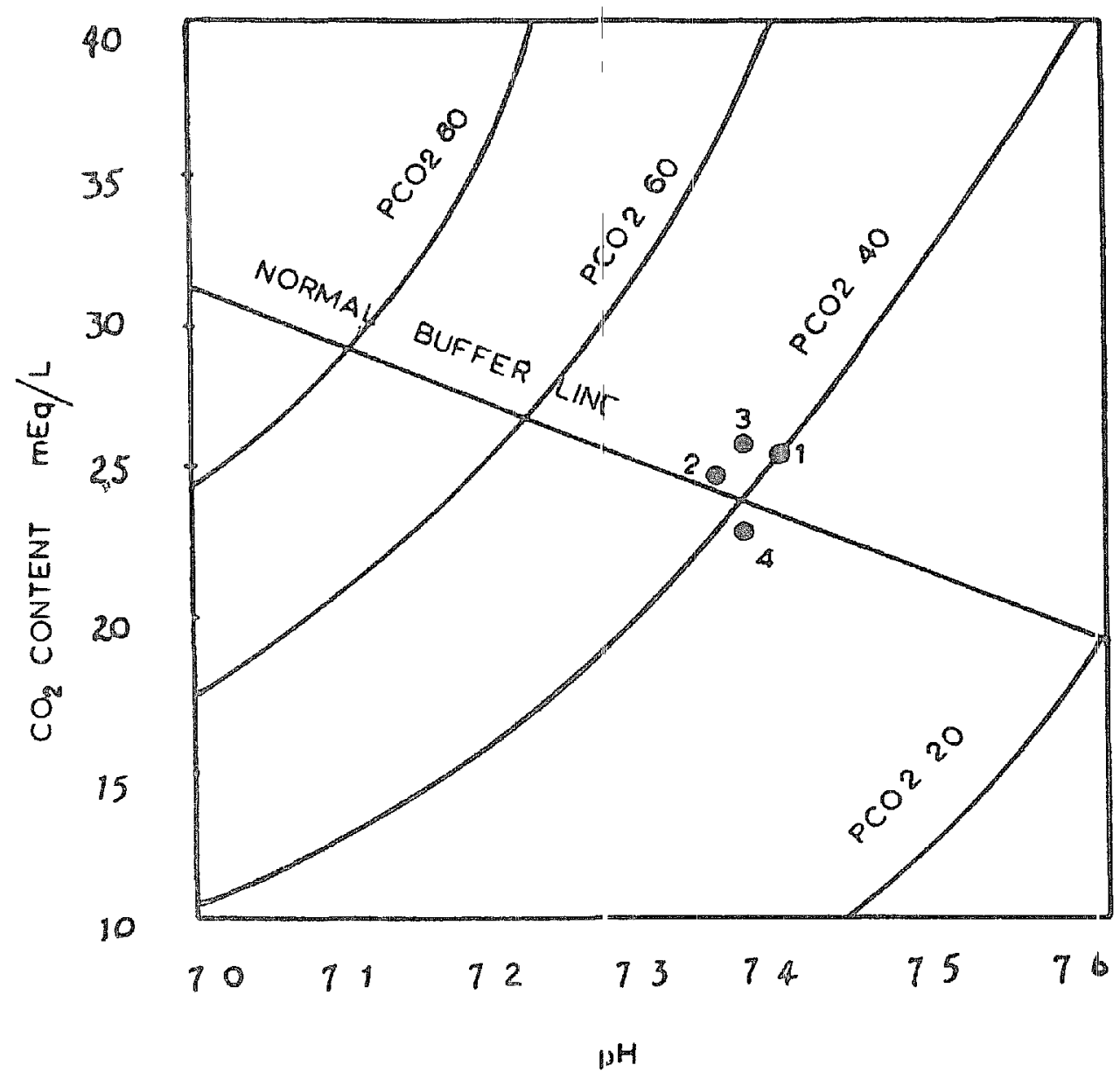

Fic URE I Effect of the halothane-ether azeotrope on acid-base balance in nine patients breathing spontaneously 1 , before induction 2, during mantenance, 3 , at the end of the operation, 4, aftcr complete recovery (after Davenport ${ }^{22}$ )

This study suggests that no important variation in acid-base balance follows the administration of this agent Dobkin, ${ }^{2}$ reporting on 10 cases in 1959, reached the same conclusion It is unlikely that the cther fiaction of the azeotiope would induce the same metabolic acidosis as ether administered alone This is a question of dosage and concentration, during straight ether anaesthesia, a patient is 
exposed to a concentration of about 4 per cent for maintenance, whle with the azeotrope, for the same level of anaesthesia he will receive only 08 per cent ether vapour Hudon, ${ }^{5}$ Dobkin, ${ }^{11}$ and their collaborators reported a slight trend towards metabolic acidosis with methoxyflurane, this disturbance being, in their vew, small and insignificant

An important metabolic effect of halothane-ether anaesthesia is a change in blood glucose during its administration Blood gluoose was evaluated in 6 patients anaesthetized with the azeotrope alone, who received no dextrose perfusion durng anaesthesia $\mathbb{F}_{1}$ gure 2 summanzes the experimental data found in these

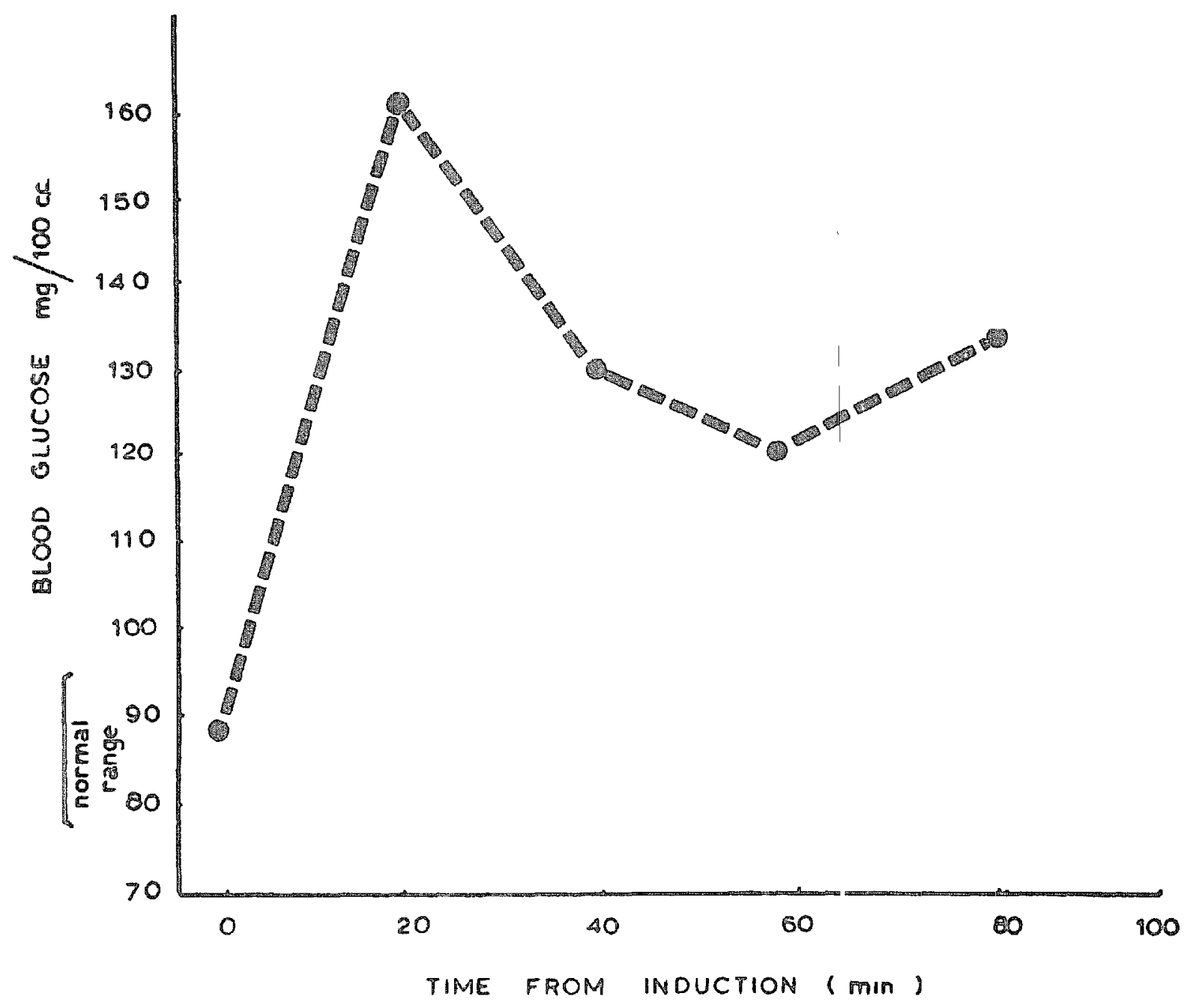

Figure 2 Mean blood glucose levels in five patients submitted to halothane-ether anaesthesia

patients Blood glucose increased significantly in every patient the mean value before anaesthesia was $088 \mathrm{gm} / / \mathrm{c}$, the concentration after 20 minutes had almost doubled, to $161 \mathrm{gm} \%$ (the significance of the difference being highly positive at the 5\% level) Later on, mean blood glucose sustanned an elevated plateau at $130 \mathrm{gm} \%$ till the end of anaesthesia Blood glucose levells were not studied once these patients left the recovery room The reason why the azeotrope can produce hyperglycaemia, yet cannot induce a metabolic acidosis, is unknown at the present tume It only suggests that ether acidosis may be unrelated to ether hyperglycaemia ${ }^{10}$ However, this study clearly indicates that the halothane fraction does not block the hyperglvcaemia induced by the ether fraction of the azeotrope 


\section{Cardıovascular Effects}

Table II gives the major haemodynamic findings in each case

1 Heart rate This was always significantly decreased during halothane-ether anaesthesia Figure 3 illustrates this predominant effect One patient experienced nodal rythm, an airhythmia which is commonplace with methoxyflurane, halothane, and even with ether

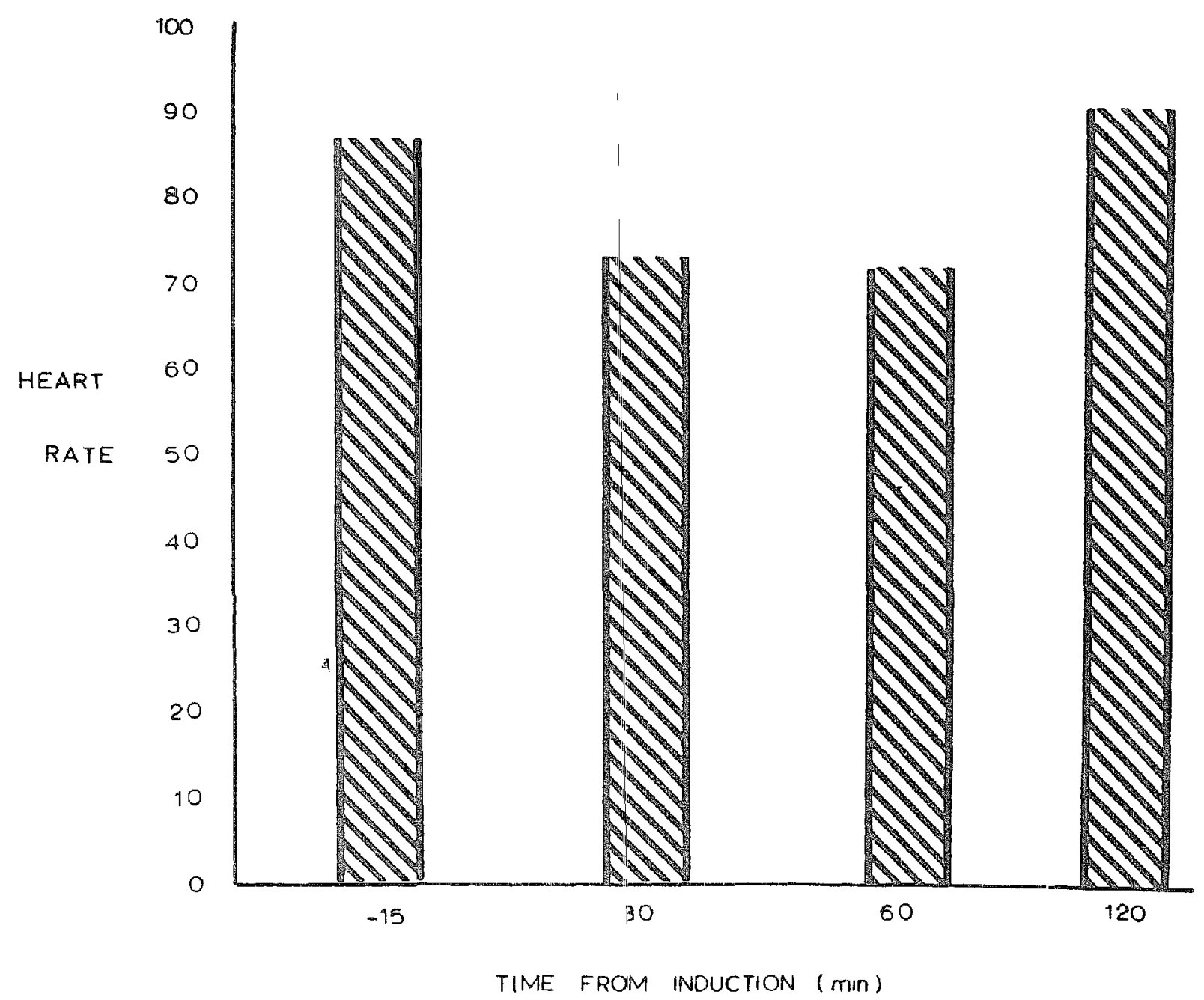

Figurf 3 Aitrigge heart rates in mine patients anaestheticed with the halothaneether azeotropic mixture

2 Blood pressuie With the patients moderately andesthetized with the azeotrope, the deciease in aiterial systolic pressure was very shight-from a mean of $126 \mathrm{~mm} \mathrm{Hg}$ before to $109 \mathrm{~mm} \mathbb{H g}$ during mantenance $(P<001)$ Diastolic pressure did not vary Postoperatively, the blood pressure remained at preanaesthetic levels in most of our patients Incidentally, this small disturbance in arterial blood pressure was very similar to the one we noliced during methoxvHurane anaesthesia

3 Cardiac output Although three groups of investigators have reported the occurrence of myocardial depression during halothane-ether anaesthesia, the data presented above demonstiate that in all our cases the administration of the azeotrope was followed by a sustained increase in cardiac output during surgery The cardiac output at rest for the 9 patients considered to be in a basal state averaged $4973 \mathrm{c} \mathrm{c}$ per minute Mantenance of anaesthesia was accompanied by 
an increment in cardiac output to a mean of $6692 \mathrm{c} \mathrm{c}$ per minute, this $\$ 46$ per cent increase, submitted to Student's t-test, proved to be significant at the 5 per cent level Only when overdosage was obtained and blood pressure reduced to marked hypotensive levels did the cardiac output decrease In no instance did cardiac output decrease after anaesthesia mean cardiac output at emergence was $5550 \mathrm{c}$ c per minute, this slight increase being insignificant $(+11 \%, P>005)$ In four of these studies, the cardiac output did not rise appreciably immediately after induction, this is due to higher concentrations and deepei anaesthesia concomitant with the induction period

On the whole, this picture is quite different from what we observed in 20 normocapnic patients studied under comparable conditions durng methoxyflurane anaesthesia From a mean cardiac output of $5549 \mathrm{c} \mathrm{c}$ per minute before induction, 75 per cent of those patients presented a 20 per cent decrease in their cardiac output during mantenance, and 60 per cent experienced d 38 per cent decrease in the recovery room

4 Peripheral resistance Vasodilatation is a peculiar feature of halothane-ether anaesthesia This statement should be easily accepted, it is substantiated by the fact that both ether and hatothane have been reported to lower peripheral resistance Total peripheral resistance fell markedly and constantly in our 9 patients during maintenance with the azeotrope initially at 1836 dynes $/ \mathrm{sec}^{-5}$, it fell to 1215 dynes during mantenance (mean decrease: 33\%, $P<0001$ ) In the recovery room, these patients still exhibited, although to a lower degree, some residual vasodilatation which accounted for their excellent colour their skin was pink, dry, and warm (mean resistance 1456 dynes/sec $\mathrm{cm}^{-5}$ ) In order to confirm this vasodilatation during halothane-ether administration, cutaneous temperature was monitored with a Yellow Spring Thermistor thermometer in 5 patients during extrathoracic and extra-abdommal operations Very soon after induction, each patient showed a $3^{\circ} \mathrm{F}$ increase in skin temperature, this increase being sustaned afterwards for the whole duration of anaesthesia Incidentally, this is the usual increase occurring after surgical or pharmacological sympathectomy Meanwhile, the central temperature changed very little This vasodilatation is conspicuous on the whole body skin surface, but is particularly well illustiated at the level of the vascular network of the bulbar conjunctiva Figure 4 gives pictures of the same eye before and during anaesthesia with the azeotrope They show an unquestionable increase in vascularity Micrometric measurements of these vessels beneath the microscope as they appear on colour slides disclosed a 45 per cent increase in the calibre of conjunctival vessels duing anaesthesia

Methoxyflurane departs widely from these features Its administration has been shown to produce in most of our patients a significant increment in peripheral resistance, this vasoconstriction being related to the concomitant fall in car diac output Figures 5 and 61 epresent this vasoconstriction as manifested at the level of the bulbar conjunctiva before, during, and after anaesthesia with this drug

5 Myocardal work Left ventıcular work aganst pressure was calculated as the product of mean brachial arterial pressure and cardiac output, and expressed in kilogram-metres per minute ${ }^{12}$ The omission of kinetic energy in this calculation 


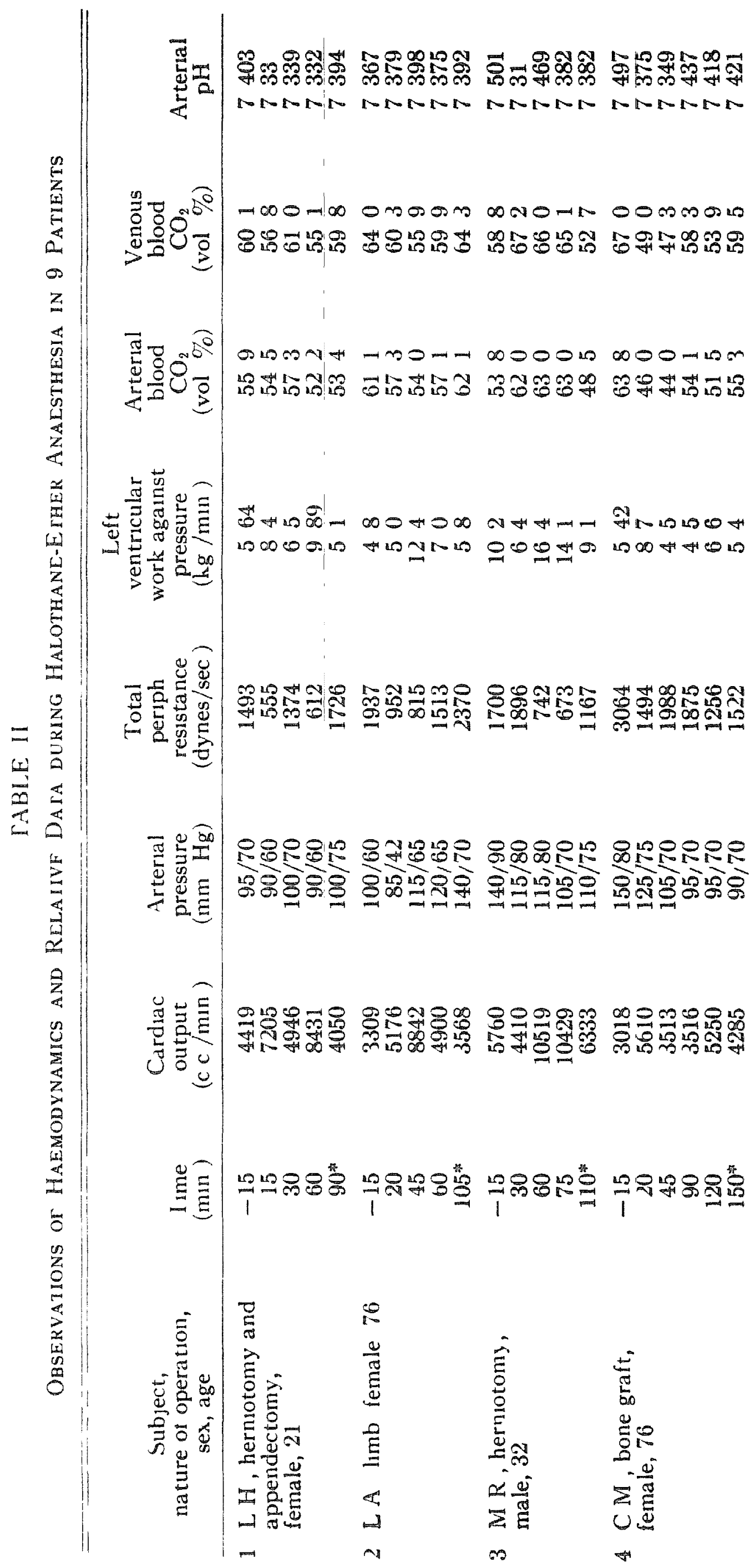




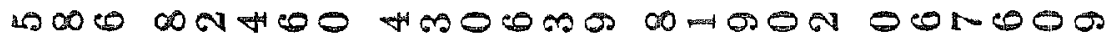

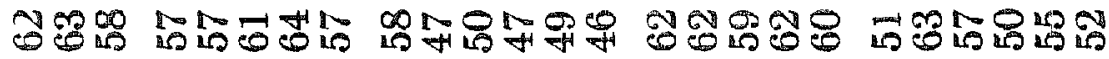

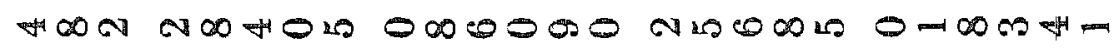

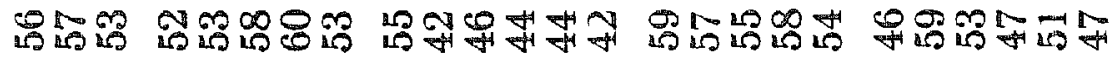

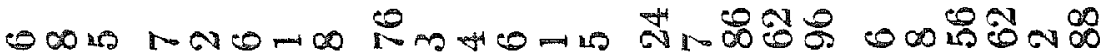
극 N N

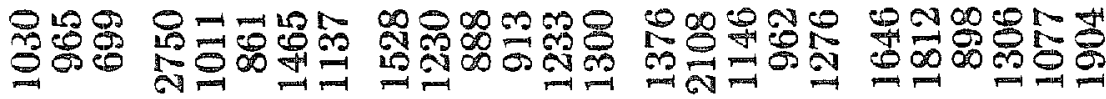

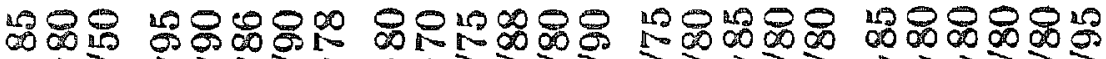

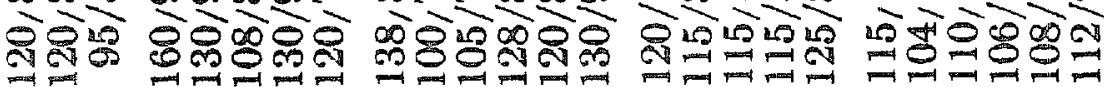

붕ㅇำ ․ㅗำ

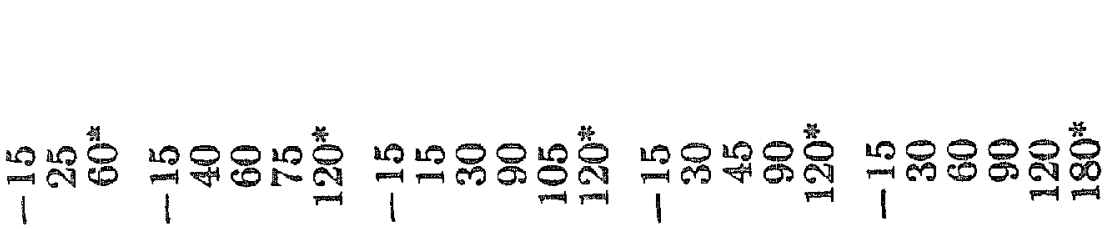

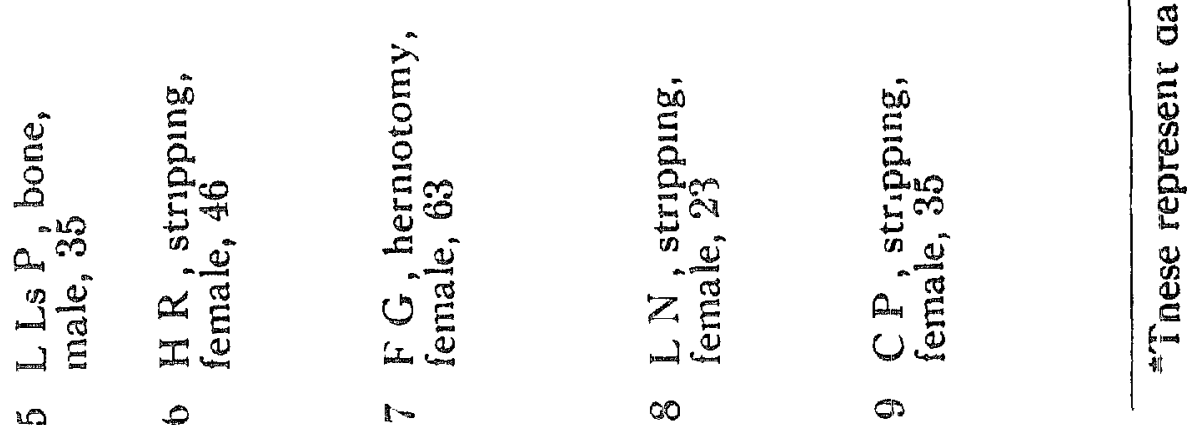



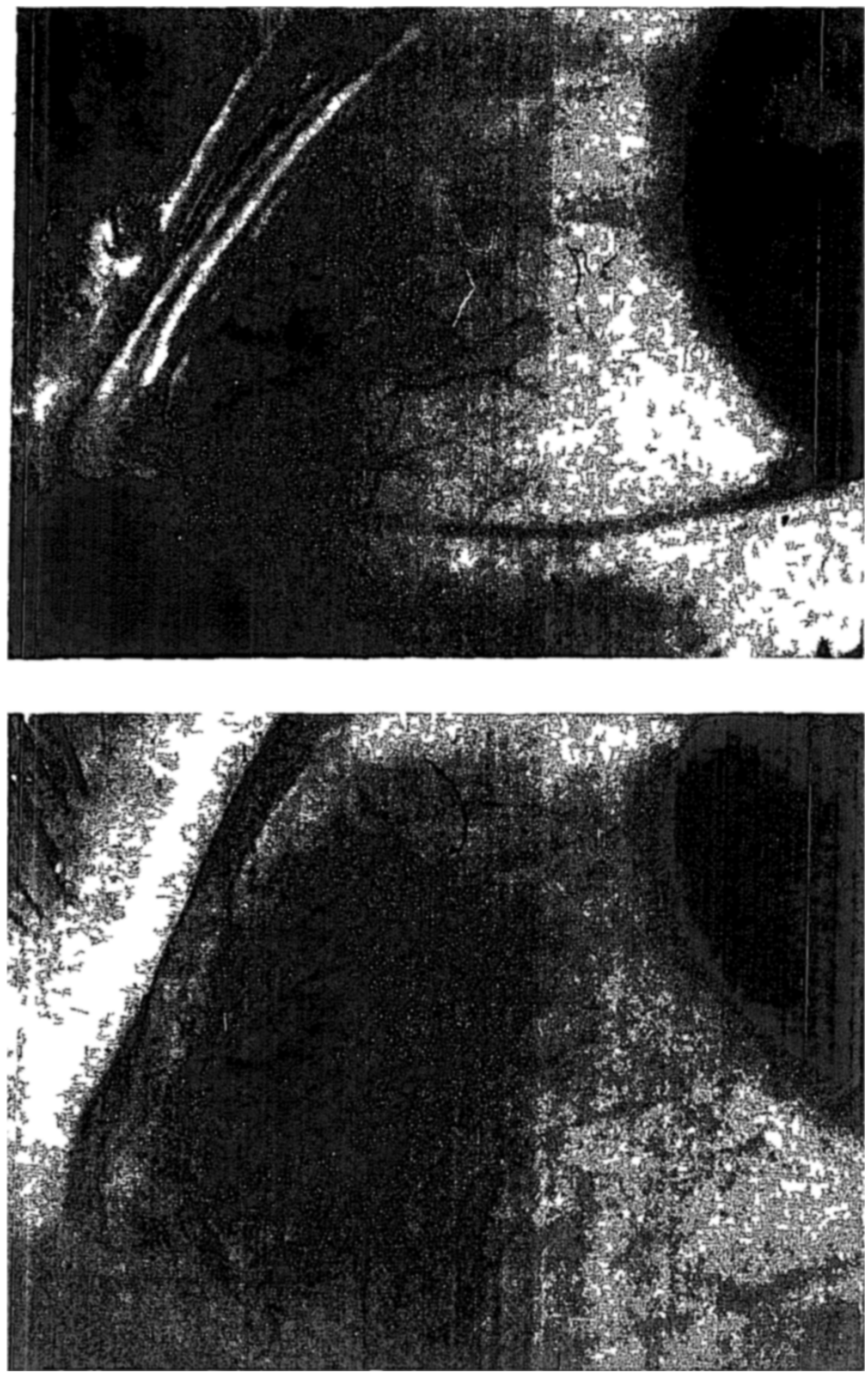

Ficure 4 Aspect of the onj $n t$ val as lar $n t$ ork befor (top) and $d$ ng (bott $m$ ) halotha ethe anae the a ( 11 gn $f$ at on 53 ) 

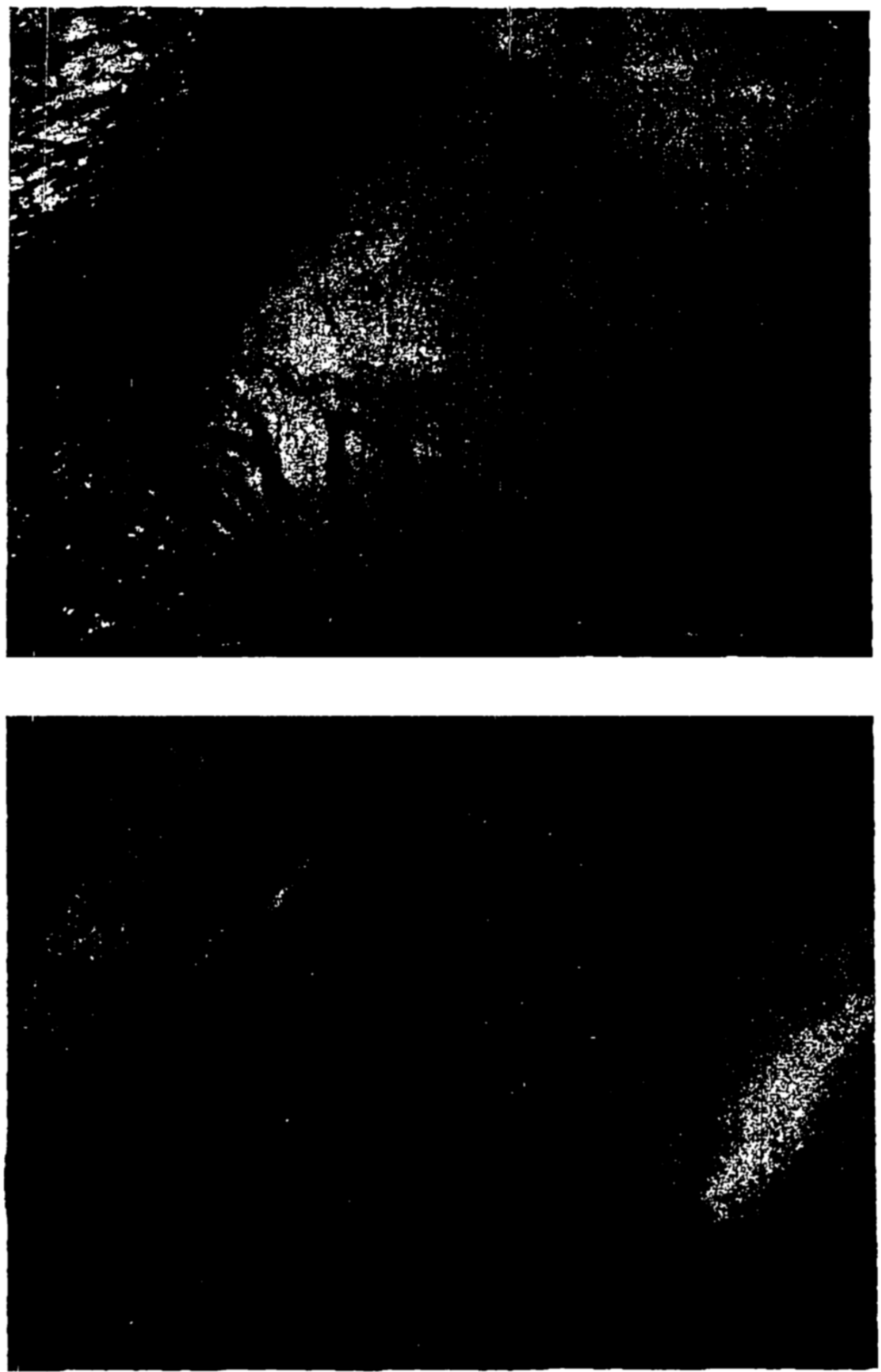

Frgure 5 Aspect of the bulbar conjunctiva before (top) and dunng (battom) methoxy flurane anaesthesia (Magnification 53 ) 


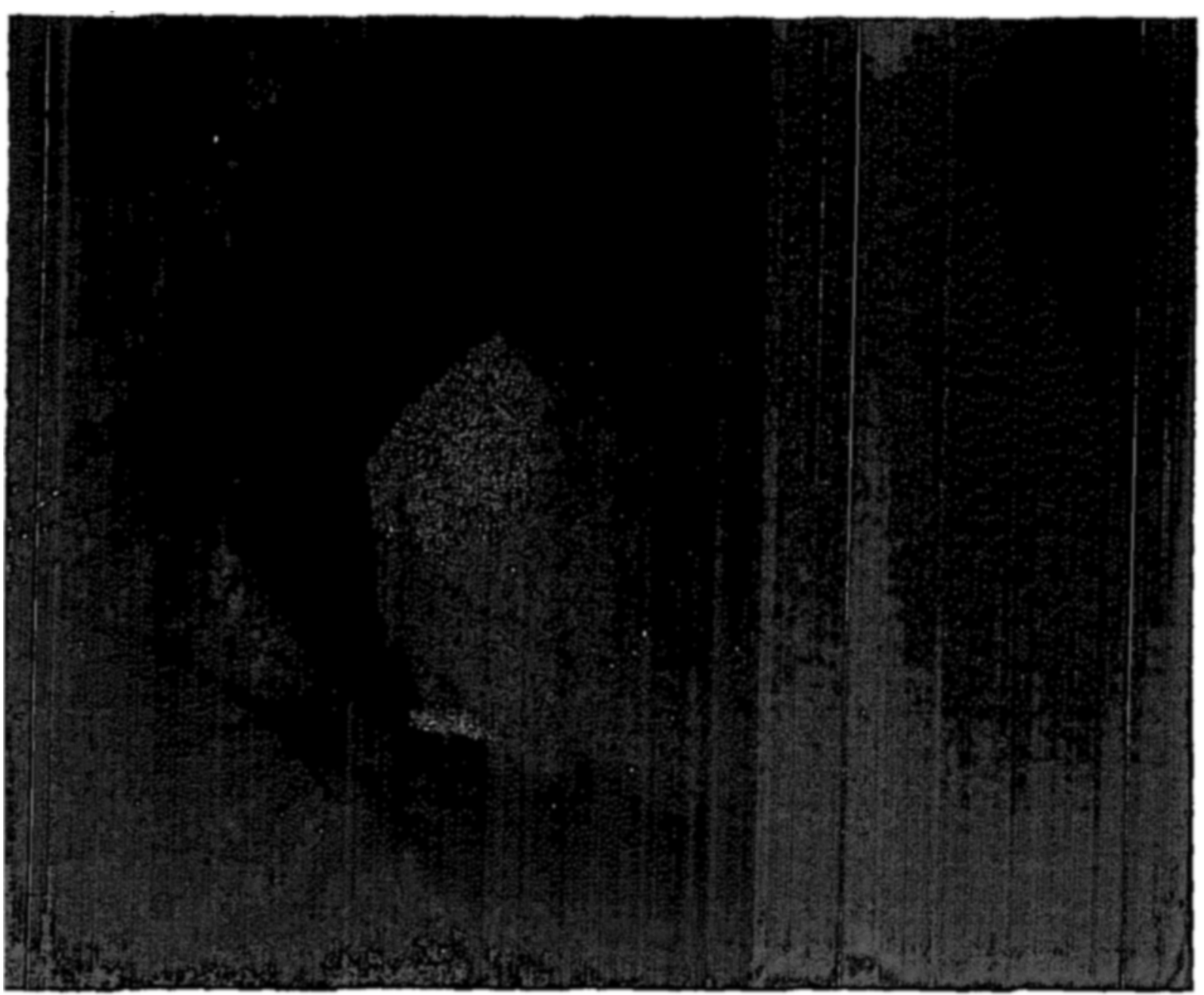

Frgure 6 Aspect of the bulbar conjunctiva after methoxyflurane anaesthesı (Magnification 53 )

ordinarily introduces no senous quantitative error Durmg halothane ether anaes thesia myocardial work agamst pressure as shown from data in Table II was not decreased proportionally to the decrease in peripheral resistance load thus suggesting that even if vasodilatation was beneficial to the heart in the sense of efficiency the inotropic activity of the heart was further enhanced by some hormonal humoral or reflexogenic mechanism

\section{Discussion}

We shall now try to give tentative explanations of our results The data pre sented above suggest that when a moderate dosage of the halothane ether azeotropic mixture was administered to patients two major dynamic alterations were induced vasodilatation and increase of cardiac output Clinical experience leaves little doubt in our minds that both effects occur and are of significance

The ability of halothane to cause vasodilatation and to block effectively the excitatory effects of catecholamines on blood vessels has been repeatedly noted There also exists some evidence of inhibition of the adrenal medulla during its administration However as reported by Burn ${ }^{13}$ and Millar and Morris ${ }^{14}$ this blockade is rather incomplete at the level of ganglia and synapses and most probably does not inhibit the release of the adrenergic transmitter in response to adrenergic nerve stomulation This partial blockade seemingly takes place in the vascular wall itself 151617 on alpha adrenergic receptors through a mechanism of inhibition or competition This inference gains additional confirmation from 
the fact that vasopressors which act specifically on alpha receptors command a poorer response during halothane anaesthesia, so it is possible that the rather impressive vasodilatation seen during halothane-ethe, anaesthesia might be due to the effective inhibition of neurogenic tone by direct action of the halothane fraction on vessels

On the other hand, halothane-ether seems to afford some protection to the heart itself This seems logical if one remembers that cardiac muscle and the coronary vascular bed are essentially lackıng in alpha seceptors ${ }^{18}$ Adrenergic blocking agents, which readily block alpha receptors, have been shown to have no direct effect on the heart itself Nickerson ${ }^{19}$ reports in his review of the question that none of a wide variety of natural and synthetic agents which effectively block the excitatory effects of epinephrine in smooth muscle is capable of giving a clear-cut blockade of its excitatory effects in mammalian heart Goodman and $\mathrm{G}_{1} \mathrm{Iman}^{20}$ are in complete agreement with this statement In ther view, adrenergic stimulation of the heart is yet possible after adreneigic blockade So the heart during light and moderate halothane anaesthesia is potentially able to answer adrenergic stimulation This is where the ether fraction of halothane-ether comes in Ether has been shown to improve ventricular function and cardiac efficiency by its stimulating action on sympathetic centres Whether this stimulation is neurogenic or humoral or both at the same moment is yet unknown One fact remains experiments designed to demonstrate that ether administration reduced the contractle force of the heart were performed either on isolated mammalian hearts or in sympathectomized individuals But during clinical halothane-ether anaesthesia, the sympathetic nervous tracts leading to the heart remain relatively unaltered, and seemingly able to fire at a high rate The increase in cardiac output we noted in our patients is strong presumptive evidence that this drug had, either by its direct action on the heart or by an indirect action through sympathetic stimulation, improved ventricular function and enhanced cardiac efficiency as a whole

One need not fear sympathetic activity during anaesthesia In our opinion, every anaesthetic agent currently in use leaves some degree of wakefulness to the sympathetic system One can praise an anaesthelic drug whose administration weakens sympathetic centres, interrupts adrenergic seflexes at the level of the ganglia, isolates the adrenal medulla, and even abolishes receptor response, till the day when one is faced with the overwhelmung dilemma of providing anaesthesia to a patient whose catecholamine stores have been depleted and adrenergic system really dampened, let us say by previous reserpine treatment Then one realizes how important these sympathetic nelvous reactions are in terms of survival and response to acute stress

We have shown that methoxyflurane protects this sympathetic reactivity, but theorically through some threat to peripheral perfusion When methoxyflurane anaesthesia is prolonged or deep, direct myocardial depression is readily compensated by intense vasoconstriction of the peripherall vascular bed, which is readily appreciated clinically by the pallor of the $9 \mathrm{~km}$, decreased tegumental temperature, cyanosis of nalbeds and mucous membranes The halothane-ether azeotropic mixture departs from these features if, on the one hand, its halothane 
fraction induces sustained vasodilatation, its ether fraction, on the other hand, compensates by enhancing strength of cardiac contraction, cardiac efficiency, and output Thus, ideal conditions are set up for visceral perfusion According to hydraulic principles, it is far more logical, in order to maintain ideal visceral perfusion, to dilate the peipheral vascular bed while stımulating the pump, than either to constrict the periphery after having depressed the pump, or to depiess both vascular tone and myocardial action $F$ al from being illogical ${ }^{21}$ the azeotrope proves to be a pharmacologically sound, balanced association, one component correctung some deficiency of the other

Finally, it must be recognized that with very deep anaesthesia, with the azeotrope, the heart is weakened by drect action of the drug on the myocardium itself If we combine $(a)$ the beneficial effer $t$ of decreased peripheral resistance on the heart, $(b)$ the effect of sympathetic reflex stimulation, and $(c)$ the dnect weakening action of halothane-ether on the heart, we come to the conclusion that, in light to moderate planes of anaesthesia, the first two factors predominate, with a deepening level of narcosis, the three factors may well cancel out, with very deep anaesthesia, cardiac output is diminished to an extremely low level ${ }^{1}$

\section{Summary and Conclusion}

The administration of halothane-ether azeotropic mixture to the surgical patients included in this study produced no iespiratory depression, no acid-base disturbances, a clear-cut hyperglycaemia, bradycardia, a definite reduction in peripheral resistance, and an elevated cardiac output The above observations suggest an absence of significant myocardial depression with the azeotrope when used in normal clinical concentrations A sustaned increase in myocardial efficiency is produced, which might be beneficial in teims of visceral perfusion In our opinion, cardiac sympathetic nerves and beta xeceptors are not blocked by the halothane fraction, their activation by the ether fraction being a major tactor of safety for the heart Mutual corrective effects of these two fractions result in a sound, balanced andesthetic state

So tar halothane-ether and methoxyflurane have been shown to differ in many iespects In the future, it will be possible to stress with more precision the indications for each For the time benng, what we appreciate most in methoxyflurane is its wide margin of safety and the remarkable stability it gives to haemodynamics during mantenance What we appreciate most in the azeotiope is its flexibulity (at the price, it is true, of a somewhat narrower margin of safety) and the preservation of a warm, pink, and dry patient who, to the satisfaction of all concerned, will fall asleep quickly and will rapidly awaken from sleep *

\section{REFERENCES}

1 Wyant, G M, Merriman, J W, Harland, I H, \& Donaldson, $H$ V The Cardiovascular Effects of Azeotropic Halothane-Ether Canad Añaesth Soc I 7 91-9 (1960)

"This investigation was madt possible by a grint from Averst, McKenna and Harrison, Montreal, $\mathrm{PQ}$ 
2 Dobinin, A B, Drummond, B A, \& Purkin, N Anaesthesia with the Azeotrople Mixture of Halothane and Diethyl Ether Brit I Anaesth 31 53 (1959)

3 Déchếne, J P, Hébert, C \& MCClish, A Halothane-Ether in Cardiac Surgery Canad Anaesth Soc J 9 61-74 (1962)

4 Price, H L General Anaesthesid and Circulatory Homeosta'ss Physiol Rev 40187 (1960)

5 Hudon, F, Jacques, A, Dery, R, Roux, J, \& Menard, J Respiratory and Haemodynamic Effects of Methoxyflurane Anaesthesia Canad Anaesth Soc J 10 442-68 (1963)

6 Aperia, A Hemodynamic Studies Scand Arch Physıol 83, suppl 16 (1940)

7 Guyton, A C Circulatory Physiology Cardiac Output and Its Regulation, chap 19, p 301 Philadelphia and London W B Saunders Co ( |963)

8 Severinghaus, J W \& Cullen, S C Depression of Myocardium and Body Oxygen Consumption with Fluothane Anesthesiology 19165 (1958)

9 Adriani, I The Chemistry and Physics of Anaesthesia, pp 711-12 Springfield, Ill Charles C Thomas, Publisher (1962)

10 Greene, $\mathrm{N}$ M Inhalation Anesthetics and Carbohydraile Metabolism, pp 83-6 Balt1more, Md Williams and Wilkins Co (1963)

11 Dobmin, A B, Song, Y, \& Briswick, V G The Effect of Methoxyflurane Nitious Oisde Anaesthesia on Arterial $\mathrm{pH}$, Oxygen Saturation, $\mathrm{PaCO}_{2}$, and Plasma Bicarbonate in Man Anesthesiology 23601 (1962)

12 Best, G H \& Taylor, N B Physiological Basis of Mddical Practice, 5th ed, p 141 Baltimore, Md Williams and Wilkıns Co (1950)

13 Burn, I H, Epstein, H G, Feigan, G A, \& Paton, W D M Some Pharmacological Actions of Fluothane Brit Med J 2479 (1957)

14 Millar, $R$ A \& Morris, $M$ E Induced Sympathetic Stinulation during Halothane Anaesthesia Canad Anaesth Soc J 7423 (1960)

15 Burn, J H \& Epstein, H G Hypotension due to Halcthane Brit J Anaesth 31199 (1959)

16 Price, M L \& Price, H L Effects of General Anaesthetics on Contractile Response of Rabbit Aortic Strips Anesthesiology 2316 (1962)

Price, H F Circulatory Actions of General Anepthetic Agents and Homeostatic Rioles of Epmephrine and Norepinephrine in Man Clin Pharmacol Therap 2163 (1961)

17 Deutsch, S, Linde, $H$ W, Dripps, R D \& Price, H L Circulatory and Respiratory Actions of Halothane in Normal Man Anesthessology 23631 (1962)

18 Moran, N C \& Perkins, M E An Evaluation of Adrenergic Blockade of the Mammalian Heart J Pharmacol \& Exper Therap 133192 (1961)

19 Nickerson, M The Pharmacology of Adrenergic Blockade Pharmacol Rev 1 27-101 (1949)

20 Goodman, L S \& Gilman, A The Pharmacological Basis of Therapeutics, 2nd ed, p 483 New York Macmillan Company (1955)

21 Jorinstone, M, Evans, V, \& Murphy, $P$ V The Halothane-Ether Azeotrope An Illogical Mixture Canad Anaesth Soc J 8 53-63 (1961)

22 Davenport, $H$ The ABC of Acid Base Chemistry, 4th ed Chicago The University of Chicago Press (1958) 